\title{
Winter quarters of wetland ground beetles (Coleoptera, Carabidae) in South Scandinavia
}

\author{
J. Andersen
}

Received: 12 December 2010/Accepted: 10 January 2011/Published online: 23 January 2011

(C) The Author(s) 2011. This article is published with open access at Springerlink.com

\begin{abstract}
Sites at various distances from eutrophic and mesotrophic lakes and fens on the island Öland in southern Sweden were systematically surveyed in summer (MayAugust) and autumn (late September-October) to elucidate the hibernation sites of wetland carabid beetles. Thirty-five of 47 wetland species were found in their winter quarters. In areas $\leq 50 \mathrm{~m}$ from the lakes and fens, the observed as well as the estimated number of hibernating wetland species was higher in mesic to dry sites than in wet or moist open sites. Very few overwintering beetles were detected far $(\geq 120 \mathrm{~m})$ from the water. There was no significant difference in the frequencies of macropterous and dimorphic (brachypterous) species and individuals hibernating close to, and more distantly from, water. Individuals of small species hibernated closer to water than larger ones. At least in Scandinavia, there is no convincing evidence that wetland species hibernate far away from water, migrating by flight. A considerable number of the species that were collected in their winter quarters are rare and redlisted in at least one of the Scandinavian countries. Winter quarters situated in mesic and dry meadows and woodland close to lakes and fens had the highest number of red-listed species. Therefore, it is of fundamental importance to protect such sites. Threats to the integrity of the current habitats are logging and various transformations of meadows, e.g. digging and removal of large objects such as stones. Cessation of grazing by cattle may also have a negative effect.
\end{abstract}

J. Andersen ( $\square)$

Department of Biology, Faculty of Science,

University of Troms $\varnothing, 9037$ Tromsö, Norway

e-mail: johan.andersen@ib.uit.no
Keywords Carabidae $\cdot$ Hibernation sites - Wetland . Red-listed species $\cdot$ Conservation value

\section{Introduction}

Many carabid beetle species occur in wetland habitats in the holarctic region (Lindroth 1961-1969, 1985-1986; Lott 2003; Freude et al. 2004; Andersen and Hanssen 2005). Over large parts of the northern hemisphere wetlands are affected by human activity (Dynesius and Nilsson 1994; Pringle 1997; Ødegaard 2006). Wetlands support many vulnerable or endangered species; $39 \%$ of the Swedish redlisted ground beetle species live at the fringes of freshwaters including bogs and mires (Gärdenfors 2005). Although knowledge about the ecology of the wetland species in their active period (spring-summer) is fairly good, available information about the hibernation strategies of the species is quite fragmentary (Krogerus 1948; Murdoch 1966; Thiele 1977; Andersen 1978, 1983, 1985a, b, 1986, 1989, 1997; Paje and Mossakowski 1984; Lindroth 1985-1986; Sowig 1986; Siepe 1994; Huk and Kühne 1999; Lott 2003; Kleinwächter and Burkel 2008; Kolesnikov 2008; Schreiner and Irmler 2009). To ensure vulnerable and endangered species are protected and adequately managed, knowledge about their overwintering ecology is of fundamental importance.

The present paper, using information from the island Öland in Sweden, focuses on the choice of winter quarters of wetland carabid beetles typical of fens and fringes of eutrophic and mesotrophic lakes in southern Scandinavia. The following questions were addressed: where are the winter quarters of the wetland species, and especially of the red-listed species, situated relative to their summer locations and what are the most important characteristics of 
these sites? Additionally, we ask whether the choice of type of winter quarters is associated with size or wing development.

\section{Materials and methods}

Location

Öland $\left(56.2^{\circ} \mathrm{N}-57.4^{\circ} \mathrm{N}\right)$ is situated in the Baltic Sea. The island is very flat (max. elevation $57 \mathrm{~m}$ ). It is made of limestone and much of the loose sediments are also rich in lime. The mean temperature in the warmest month (July or August) is between 15.8 and $16.8^{\circ} \mathrm{C}$ and between -1.9 and $-0.7^{\circ} \mathrm{C}$ in the coldest month (February). Autumns are mild, with temperatures ranging from 7.9 to $9.1^{\circ} \mathrm{C}$ in October. The mean yearly precipitation is between 431 and $532 \mathrm{~mm}$. The meteorological data are from the period 1961-1990 and stem from Alexanderson et al. (1991). The southern part of Öland is situated in the nemoral zone, whereas the rest of the island belongs to the boreonemoral zone (Moen 1998). The southern part of Öland therefore belongs to the northernmost part of the prevailing vegetation zone of Central Europe.

\section{Sampling methods and procedures}

Carabid beetles were sampled in fens and at lakes and ponds in May, June and August in the period 2004-2008. Sites in increasing distance from, and height above, these summer habitats of the wetland species were selected systematically and examined in October 2007 and 2008. Dry and mesic habitats far from water were investigated in May-August 1991-2008 and in late September and October 1993, 1998, 2007 and 2008.

The investigations were based on timed hand-collecting (time-catch). In mesic or dry sites with a silty or sandy soil, the vegetation and loose material were systematically removed. In forests and one of the meadows, the time-catch method also involved sifting of litter and moss through a sieve with a mesh size of $5.5 \mathrm{~mm}$. The sifted material was carefully examined indoors. Fens and shores mainly had a soft substratum. Besides removing loose material, trampling was therefore practiced when the substratum was watery. In these locations the substratum and vegetation were pressed below the water surface and the beetles were forced out of their hiding places and picked up. Some places had many large stones and in these locations beetles were searched for under the stones. The number of large stones (area of underside of each stone about $0.03-0.06 \mathrm{~m}^{2}$ ) that were turned and investigated and the time used in the sampling were noted. Small stones were summed up to equalize large stones. The correlation between the number of large stones that were investigated and the time used in the collecting was very high $\left(r^{2}=0.877, p<0.001\right.$; number of sample sets: 15$)$. Time therefore gives a good measure of the number of large stones that were investigated. The ambient temperature during the sampling was $10-15^{\circ} \mathrm{C}$ in autumn and 14 to $>26^{\circ} \mathrm{C}$ in summer. All searching was conducted in dry weather when it was usually sunny.

Environmental variables and habitats

Based on the moisture requirements of plants, which were derived from Ekstam et al. (1984), Lid and Lid (2005) and Mossberg and Stenberg (2007), the mean soil mositure content was calculated as follows:

$a=(H-X) /(H+X+M)$

where $a$ is the moisture index, $H$ the number of plant species adapted to wet or moist soils or water, $X$ the number of species requiring dry or dry to mesic sites and $M$ the number of species requiring mesic sites. Most of the plant species belonged to category $H$ in sites with $a$ values $\geq 0.28$ and such sites, were further discriminated between wet and moist, with wet sites being those permanently wet or covered by water and with hydrophytes and helophytes comprising $21 \%$ or more of the total number of plant species. The $a$ values of such sites were $\geq 0.89$. The moist sites are periodically wet, but the hydrophytes and helophytes make up less than $21 \%$ of the plant species. The $a$ values varied between 0.28 and 0.65 . The mesic sites have $a$ values between -0.17 and 0.04 . The dry sites have $a$ values between -0.94 and -0.30 and a majority of the plant species require dry soils.

Evaluations of the nutritional value of the soil or the water were also based on plant species composition. The soil and water overlying limestone bedrocks on Öland are alkaline ( $\mathrm{pH}$ value about 8 ), but rather poor in nutrients (Ekstam et al. 1984). Accordingly, such environments have a lower proportion of plant species requiring nutritionally rich conditions than plants on clayish or fine sandy soils $(21-31 \%$ vs. $33-80 \%)$. Sites in which $50 \%$ or more of the plant species require nutritionally rich soils were classified as eutrophic or rich, the others as mesotrophic. Vegetation coverage was judged according to the scale of Hult-Sernander (Andersen 1970). Vegetation less than $10 \mathrm{~cm}$ high was regarded as low. Each plant species analysis covered the whole area of the site in which the carabid beetles were sampled.

The most important characteristics of the sites are given in Table 1. The water level in the wetlands on Öland is normally highest in winter- early spring and lowest in summer (Ekstam et al. 1984), but levels may vary between years. Thus, the water level was high in August 2005 and 


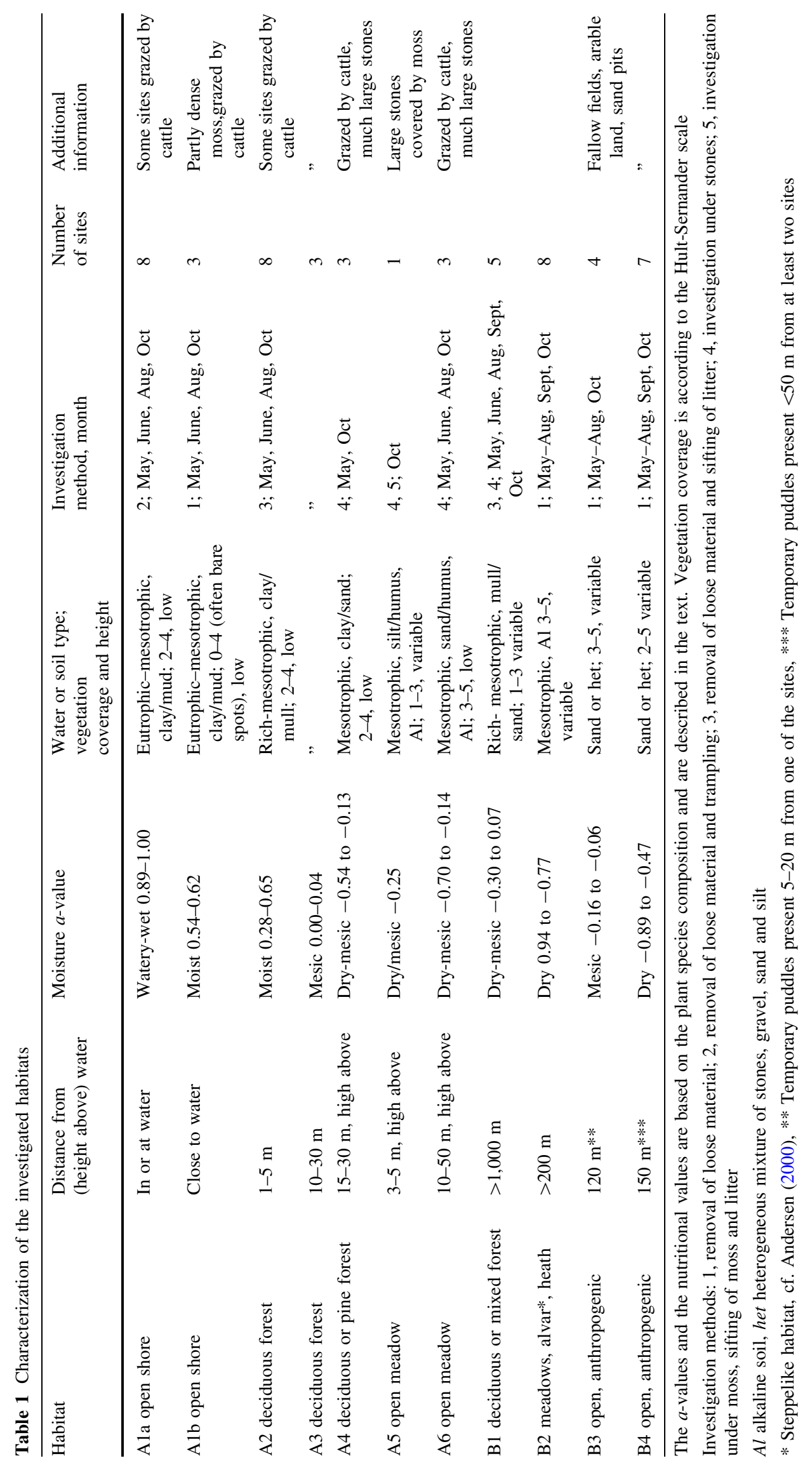


May 2006, but low in June 2004 and May 2008. The lowest water level was observed in October 2008.

Habitats A1-A4 and A6 represent an increasing distance from, and an increasing height above water, and A4-A6 are hardly ever flooded. Some of the sites in habitat A2 are situated in moderately sloping terrain, in one case in a steep slope. The drainage at such places is probably good. At three of the lakes, there is a continuous mat of low vegetation from the water up to dry forests (A4) and meadows (A6). These areas are grazed by cattle.

\section{Species}

Species identifications were made using Lindroth (19851986) and Freude et al. (2004). Carabid beetles were divided into wetland species, other forest species and other Carabidae groups using information provided by Lott (2003), Lindroth (1985-1986) and Freude et al. (2004). However, Lott (2003) considers Loricera pilicornis, Nebria brevicollis, Trechus secalis and Pterostichus strenuus as wetland species though they are quite euryhygric in Scandinavia (Lindroth 1945; Andersen unpublished data) and together with a number of other species they are treated collectively as: other forest species. Bembidion femoratum and B. tetracolum, which according to Lott (2003) are riparian, are also euryhygric in Scandinavia (Lindroth 1945) and were therefore placed in the category: other Carabidae. Based on information in Lindroth (1945, 1985-1986), Hansen (1968), Ljungberg (2002) and Freude et al. (2004) the wetland species were divided into two groups: species that prefer open shores (SHO species) and species preferring moist or wet forest (FOR species). A number of species of the latter category also occur regularly on open, sun-exposed shores. However, some species are not easily placed according to this division.

The beetles were divided into two size categories: small species ( $<7 \mathrm{~mm}$ length) and medium sized to large species ( $\geq 7 \mathrm{~mm}$ ). $7 \mathrm{~mm}$ was chosen as a size limit since this value roughly marks the division between what are regarded as small and medium sized and large species (see Lindroth 1985-1986 and Freude et al. 2004). Several wetland species are wing-dimorphic or polymorphic. The degree of development of the wings of individuals of nine of these species was examined and the following states were distinguished: (a) Brachypterous: wings without reflexed apical part, shorter and more narrow than one elytron and therefore without flight ability. (b) Wings of about same length as elytra, reflexed apical part weakly developed, of uncertain flight ability, (c) Macropterous. Wings much broader and longer than one elytron and with a well developed reflexed apical part, with flight capacity. Information in Lindroth $(1945,1985-1986)$ indicates that more than $80 \%$ of the wetland species are imaginal hibernators.
Most of the species were therefore expected to occur as adults in autumn.

Statistical methods

Estimates of wetland species number $\left(S_{\text {est }}\right)$ were made for autumn samples in habitats A1, A4 and A6, using Chao (1984): where $S_{\text {est }}=S_{\text {obs }}+\left(N^{2} / 2 \mathrm{~K}\right)$ and $S_{\mathrm{obs}}$ is the observed number of wetland species, $N$ is the number of species represented by a single individual and $K$ the number of species represented by two individuals. $N$ and $K$ include all the collected carabid beetle species in each of the habitats that were compared. The material from A4 and A6 came from one lake, while A1 also includes material from three other freshwater fringes. Sampling in each of the habitats A4 and A6 was made within areas of approximately $110 \mathrm{~m}^{2}$, whereas collecting within A1 covered a larger area. A1 also had heterogeneous plant cover, plant species composition and nutritional value of the soil, while the same parameters were relatively uniform in A4 and A6.

Differences in the frequencies of individuals are not directly comparable as different sampling methods were used in different sites. Larger carabid beetles $(\geq 7 \mathrm{~mm})$ also have a greater tendency to hide under large, heavy objects than small species $(<7 \mathrm{~mm})$ (Andersen unpubl. data) and habitats either lacked stones (A1-A3, partly A5) or they contained spots with as well as without stones (A4 and A 6). Habitats were divided into comparable groups: those close to water versus those more distant from water and open sites versus forest. The frequencies of species and individuals in these habitat groups were compared by using $2 \times 2$ contingency tables $\left(\chi^{2}\right.$ with Yates' correction, when expected frequencies $\leq 3.0$ ). The tests compared the occurrence of FOR and SHO species in relation to exposure in summer and autumn, habitat distribution of small compared with larger species and of macropterous versus poly(di)morphic and brachypterous species.

According to Greenstone (1979) the time-catch method ought to be used in situations in which most variables are held constant. In the present study, the method was therefore used to compare the abundance (the number of individuals collected per hour) of species in the same sites and with the same sampling procedures at different times of the year. The abundances of the species in the sites were compared with Mann-Whitney $U$ tests. The length of each time unit varied in the tests, but it was always equally large or largest at the time of the year when the calculated abundance values were lowest.

\section{Results}

About 640 individuals of 35 wetland carabid beetle species were collected in late September and in October (Tables 2, 
3, 4). More than 100 individuals of Pterostichus nigrital anthracinus were collected in habitat A6, but could not be identified to species since they often escaped in crevices or holes in the soil.

In autumn, the total number of observed (collected) wetland species in open, wet/moist sites (habitat A1) at four lakes was 8 whereas the number of species in each of two dry/mesic habitats (A4 and A6) at one of the same lakes was 15 . With the estimate of Chao, the corresponding values were $8-9,15-32$ and $15-22$. The total number of red-listed species that was found in the zones more distant from the water (habitats A3-A6) in autumn was 8, whereas it was 5 in the zones close to water (habitats A1, A2) (Table 5).

The degree of development of the wings of nine species is shown in Table 6, whereas the habitat distribution of some categories of species is given in Table 7. No significant differences in the frequency distribution of any of the categories tabulated in Table 7 appeared at the species level $\left(\chi^{2} \leq 3.04\right)$, and this also was partly the case at the level of individuals. However, individuals of FOR species more often occurred in open habitats in autumn than would be expected according to their distribution in summer. Much of the reason for this pattern was the dominance of Pterostichus nigrita and P. anthracinus in open habitats in autumn. Furthermore, whereas the frequency of macropterous relative to dimorphic/brachypterous individuals in autumn was independent of distance from water, individuals of larger species significantly more often hibernated farther from the water than the small ones (Table 7).

Oxypselaphus obscurus and Agonum fuliginosum formed aggregates under moss in moist forest and other species were frequently found together with them. Most of the beetles that were collected in habitat A2 in October, occurred in slightly elevated parts of the terrain, often at the base of trees. The beetles were usually found in aggregates under the large stones in dry or mesic forests and dry meadows in autumn. Very few species and individuals of the wetland fauna were found far from open water in autumn (Table 4).

\section{Discussion}

The winter quarters of the beetles

Some species, which according to Lindroth (1945) and Gärdenfors et al. (2002) prefer open shores, were found in moist forest (habitat A2) in August 2005 and May 2006. They had probably been forced into the forest because of the high water level in the lakes in this period.

A majority of the wetland species seems to leave the wet or moist parts of the open shores before the winter, the estimated number of species at the shores of four of the lakes being $\leq 9$. This is also supported by a study of Krogerus (1948). Whether the few species and individuals that were present in habitat A1a in October really hibernate there or migrate later to drier sites, is somewhat uncertain. However, some carabid beetles such as Odacantha melanura, Demetrias imperialis and Agonum thoreyi, are known to hibernate in stems or leaf sheats of Phragmites and Typha in wet or moist parts of shores (Lindroth 1986).

Mesic to dry sites adjacent to fens and lakes harboured a high number of wetland species in autumn, the estimated number of such species in each of the habitats A4 and A6 being $\geq 15$ at one of the lakes. The beetles no doubt hibernate in these habitats since a majority of the species was absent in the sites during the summer. Furthermore, they formed clusters in the sites in autumn. This is a typical pattern of hibernating carabid beetles (Thiele 1977) whereas aggregations among wetland species have never been observed during the summer. Moist forests (habitat A2), which usually had soils with good draining ability, also harboured a rich carabid beetle fauna in October. The fact that the species often aggregated under moss indicates that the sites constitute their winter quarters. The relative abundance of the forest (FOR) species was higher in open habitats in autumn than in summer. This may be due to smaller differences in moisture and temperature between open and shady habitats in autumn than in summer. In addition, carabid beetles seem to be less dependent upon moisture in autumn than in summer (Andersen 1985a, unpublished data).

Lindroth (1945, 1985-1986) and Murdoch (1966) found Carabus granulatus, Oxypselaphus obscurus, Platynus livens, Agonum lugens, A. fuliginosum, Pterostichus minor, Badister unipustulatus and Panagaeus cruxmajor hibernating under bark or in decaying wood, partly close to water. The present investigation shows that these species (as well as several others) also hibernate under stones in mesic and/or dry sites near shores. When the stones were turned over, the beetles often disappeared in holes. The beetles probably dwell in the holes during the winter since carabid beetles frequently spend the cold season in the soil itself (Thiele 1977). The tendency to hide under stones was much more conspicuous among the larger species, e.g. Pterostichus anthracinus, P. nigrita and Agonum emarginatum than among the small ones, a pattern mainly explaining the high abundance of wetland species in sites farther from the water in autumn. The zones situated more distantly from water often had large amounts of stones, whereas patches close to water nearly lacked such objects. However, the pattern of moving away from water by the larger species was also evident when patches without stones were compared (habitats A1, A2 vs. A3, A5). This coincides with previuos observations that larger species 
Table 2 Number of wetland species and other groups of Carabidae collected per hour in May-August $(\mathrm{Su})$ and October $\mathrm{Au})$ in habitats close to or in wetlands on Öland
The nomencature follows Freude et al. (2004). Wing development is according to Lindroth $(1945,1949)$ and Table 6. Red-listing is according to Gärdenfors (2005), $\varnothing$ degaard et al. (2006) and DMU (2007)

b, mainly brachypterous (flightless); d, dimorphic or polymorphic; $\mathrm{m}$, macropterous (with flight ability); SHO, open shore species; FOR, forest species; F, red-listed in Norway; $\mathrm{x}$, red-listed in Sweden

* Red-listed in Denmark

\begin{tabular}{|c|c|c|c|c|c|}
\hline \multirow[t]{2}{*}{ Species } & \multicolumn{2}{|c|}{ A1 open shores } & \multirow[t]{2}{*}{$\mathrm{Au}$} & \multirow{2}{*}{$\begin{array}{l}\text { A2 } \\
\text { Moist } \\
\text { forests } \\
\mathrm{Au}\end{array}$} & \multirow{2}{*}{$\begin{array}{l}\text { A } 5 \\
\text { Dry/mesic } \\
\text { meadow } \\
\text { Au }\end{array}$} \\
\hline & $\begin{array}{l}\mathrm{a} \\
\mathrm{Wet} \\
\mathrm{Su}\end{array}$ & $\begin{array}{l}\mathrm{b} \\
\text { Moist } \\
\mathrm{Su}\end{array}$ & & & \\
\hline SHO Elaphrus cupreus $\mathrm{m}$ & 0.36 & 1.14 & & & \\
\hline SHO Blethisa multipunctata $\mathrm{m}^{*}$ & 0.53 & & & & \\
\hline SHO Dyschirius tristis m & 2.40 & 23.43 & & & \\
\hline SHO Asaphidion flavipes $\mathrm{m}$ & & & & & 1.04 \\
\hline SHO Bembidion obliquum $\mathrm{m}$ & 0.09 & & & & \\
\hline FOR B. gilvipes $\mathrm{d}$ & & & 0.67 & & \\
\hline SHO B. doris $\mathrm{m}$ & 1.60 & & 0.33 & & \\
\hline SHO B. fumigatum m & & & 3.00 & & \\
\hline SHO B. assimile $\mathrm{d}$ & 0.98 & & 4.00 & & \\
\hline FOR $B$. clarkii b & 0.09 & & 0.33 & 2.25 & \\
\hline SHO B. guttula d & 0.18 & & 0.33 & & 2.09 \\
\hline SHO Pterostichus vernalis $\mathrm{d}$ & 0.09 & & 1.33 & 3.75 & 1.57 \\
\hline SHO P. gracilis $\mathrm{m}^{*}$ & 2.49 & & & & 1.04 \\
\hline FOR $P$. nigrita $\mathrm{m}$ & 0.98 & & & & \\
\hline FOR $P$. anthracinus $\mathrm{d}$ & 0.71 & 0.57 & & & 1.57 \\
\hline FOR $P$. minor $\mathrm{d}$ & 1.16 & & 0.33 & & \\
\hline FOR $P$. diligens $\mathrm{b}$ & 0.98 & 0.57 & 0.33 & 4.50 & 8.34 \\
\hline FOR Platynus livens $\mathrm{m} *$ & 0.71 & & & & \\
\hline FOR Oxypselaphus obscurus b & & & 5.33 & 15.0 & 24.52 \\
\hline SHO Agonum thoreyi $\mathrm{m}$ & 0.27 & & & 0.75 & \\
\hline $\mathrm{SHO}$ A. piceum $\mathrm{m}$ & & & & & 0.52 \\
\hline SHO A. gracile $\mathrm{m}$ & 0.27 & & & & \\
\hline FOR A. fuliginosum $\mathrm{b}$ & & & & 41.25 & 0.52 \\
\hline $\mathrm{SHO}$ A. viduum $\mathrm{m}$ & 2.58 & 3.43 & & & 0.52 \\
\hline SHO A. emarginatum $\mathrm{d} \Phi$ & 8.10 & 9.14 & & 0.75 & 4.70 \\
\hline SHO A. lugens $\mathrm{m}^{*}$ & 0.27 & & & & \\
\hline SHO Stenolophus mixtus $\mathrm{m}$ & 0.62 & 0.57 & & & \\
\hline SHO Aculpalpus parvulus m & 0.09 & & & 0.75 & 0.52 \\
\hline FOR Trichocellus placidus $\mathrm{m}$ & & & & & \\
\hline SHO Panagaeus cruxmajor $\mathrm{m} * \Phi$ & 0.36 & & & & \\
\hline SHO Chlaenius nigricornis $\mathrm{m} * \Phi \mathrm{x}$ & 0.53 & & & & \\
\hline SHO C. tristis $\mathrm{m}^{*} \Phi \mathrm{x}$ & 0.09 & & & & \\
\hline SHO Oodes helopioides $\mathrm{m} \Phi$ & 0.98 & & & & \\
\hline FOR Badister unipustulatus m* & & & & 0.75 & \\
\hline FOR $B$. peltatus $\mathrm{m}^{*} \Phi$ & 0.09 & & & & \\
\hline SHO B. dilatatus $\mathrm{m} \Phi$ & 0.18 & & & 0.75 & \\
\hline SHO Odacantha melanura $\mathrm{m} \Phi$ & 0.09 & & & & \\
\hline$\sum$ Wetland species & 27.87 & 38.85 & 15.98 & 70.50 & 46.95 \\
\hline$\sum$ Other FOR species & 0 & 0.57 & 0.67 & 0 & 9.71 \\
\hline$\sum$ Other Carabidae species & 1.00 & 2.29 & 1.00 & 0 & 18.78 \\
\hline Investigation time (min) & 675 & 105 & 180 & 80 & 115 \\
\hline
\end{tabular}

move about more than the small ones (Arneberg and Andersen 2003).

The reason why the wetland species leave the wet or moist sites in autumn may be that a majority of the species probably depend on supercooling to survive the winter (Andersen 2006). There is less risk of lethal inoculative freezing in dry habitats because the probability of contact with ice is reduced in such environments (Sømme 1995). 
Table 3 Number of individuals of wetland species and other groups of Carabidae collected per hour in May-August (Su) and October (Au) in habitats close to or in wetlands on Öland

\begin{tabular}{|c|c|c|c|c|c|c|c|c|c|c|}
\hline \multirow[t]{2}{*}{ Species } & \multicolumn{2}{|c|}{$\begin{array}{l}\text { A1a wet, } \\
\text { open shores }\end{array}$} & \multicolumn{2}{|c|}{$\begin{array}{l}\text { A2 moist } \\
\text { forests }\end{array}$} & \multicolumn{2}{|c|}{$\begin{array}{l}\text { A3 mesic } \\
\text { forests }\end{array}$} & \multicolumn{2}{|c|}{$\begin{array}{l}\text { A4 mesic/dry } \\
\text { forests }\end{array}$} & \multicolumn{2}{|c|}{$\begin{array}{l}\text { A6 mesic/dry } \\
\text { meadows }\end{array}$} \\
\hline & $\mathrm{Su}$ & $\mathrm{Au}$ & $\mathrm{Su}$ & $\mathrm{Au}$ & $\mathrm{Su}$ & $\mathrm{Au}$ & $\mathrm{Su}$ & $\mathrm{Au}$ & $\mathrm{Su}$ & $\mathrm{Au}$ \\
\hline SHO Carabus clatratus $\mathrm{b} * \phi$ & & & & & & & & 0.37 & & \\
\hline FOR C. granulatus b & & & 0.10 & & & & & & 0.41 & 0.49 \\
\hline SHO Elaphrus cupreus m & 0.47 & & 0.16 & & & & & & & \\
\hline SHO Blethisa multipunctata $\mathrm{m}^{*}$ & 0.47 & & & & & & & & & \\
\hline SHO Dyschirius tristis m & 3.94 & & & & & & & & & \\
\hline SHO Asaphidion flavipes $\mathrm{m}$ & & & & & 0.46 & & & & & \\
\hline FOR $B$. gilvipes $\mathrm{d}$ & & & 0.05 & & & & & & & \\
\hline SHO B. doris $\mathrm{m}$ & 1.41 & & 0.37 & 0.90 & & & & & & \\
\hline SHO B. fumigatum $\mathrm{m}$ & & & & 0.30 & & & & & & 0.24 \\
\hline SHO B. assimile $\mathrm{d}$ & 2.63 & 0.86 & 2.56 & 0.90 & & 2.21 & & 0.55 & & 0.24 \\
\hline FOR B. clarkii b & 0.91 & & 1.88 & 1.20 & & & & & & 0.24 \\
\hline SHO B. articulatum $\mathrm{m}$ & 0.09 & & & & & & & & & \\
\hline SHO B. aeneum d & & & & & & & & & & 0.49 \\
\hline SHO B. guttula d & 0.09 & & & & & & & & & \\
\hline FOR B. mannerheimi b & & & 0.63 & & 2.00 & & & & & \\
\hline SHO Pterostichus vernalis $\mathrm{d}$ & 0.09 & & 0.16 & 0.30 & & 0.63 & & 2.58 & & 0.97 \\
\hline SHO $P$. gracilis $\mathrm{m}^{*}$ & 0.28 & & 0.05 & & & & & 0.37 & & 0.73 \\
\hline FOR $P$. nigrita $\mathrm{m}$ & 0.66 & & 1.26 & 0.30 & & 3.16 & 0.42 & 14.03 & 0 & $\geq 20.89$ \\
\hline FOR $P$. anthracinus $\mathrm{d}$ & 0.38 & & 0.99 & & 0.77 & 0.32 & & 2.22 & 0 & $\geq \mathbf{3 . 1 6}$ \\
\hline FOR $P$. minor $\mathrm{d}$ & 1.97 & 2.14 & 1.94 & & & 0.63 & & 0.92 & & \\
\hline FOR $P$. diligens $\mathrm{b}$ & 0.66 & & 1.73 & 1.20 & & 2.21 & & 0.74 & & \\
\hline FOR Platynus livens $\mathrm{m}^{*}$ & & & 0.16 & & & & & & & 0.24 \\
\hline FOR Oxypselaphus obscurus b & & & 2.82 & 11.70 & 1.08 & 0.32 & & & & \\
\hline SHO Agonum thoreyi m & 0.28 & & 0.16 & & & & & & & \\
\hline SHO A. piceum m & & 0.86 & 0.05 & & & & & & & 0.49 \\
\hline SHO A. gracile $\mathrm{m}$ & 0.19 & & & & & & & & & \\
\hline FOR A. fuliginosum b & 0.09 & & 3.14 & 0.90 & & 0.32 & & & & \\
\hline SHO A. viduum $\mathrm{m}$ & 2.63 & 0 & 0.37 & & & & & 0.18 & & 0.49 \\
\hline SHO A. emarginatum d $\Phi$ & 1.13 & & 3.09 & & & 1.26 & 0.42 & 4.80 & 0 & 2.43 \\
\hline FOR A. duftschmidi d* & & & 1.05 & & & & & & & \\
\hline SHO A. lugens $\mathrm{m}^{*}$ & 2.72 & & & & & & & 0.18 & & 0.49 \\
\hline SHO Stenolophus mixtus $\mathrm{m}$ & & & & & & & & 0.37 & & \\
\hline FOR Anthracus consputus m & & & 0.21 & & & & & & & \\
\hline FOR Trichocellus placidus $\mathrm{m}$ & & & 0.16 & 0.30 & & & & & & \\
\hline SHO Panagaeus cruxmajor $\mathrm{m} * \Phi$ & 0.19 & & 0.21 & & & 0.32 & & 0.37 & & 0.24 \\
\hline SHO Chlaenius tristis $\mathrm{m} * \Phi \times$ & & & & & & & 0.84 & 0.18 & & \\
\hline SHO Oodes helopioides mФ & 0.66 & & 0.21 & & & & & & & \\
\hline FOR Badister unipustulatus $\mathrm{m}^{*}$ & & & 0.05 & & & & & 0.92 & & 0.24 \\
\hline FOR B. sodalis b $\Phi$ & & & 0.16 & 1.30 & 0.15 & & & & & \\
\hline FOR B. peltatus $m * \Phi$ & 0.19 & & 0.47 & 0.30 & & & & & & \\
\hline SHO B. dilatatus $m \Phi$ & 0.09 & & & & & & & & & \\
\hline SHO B. collaris $\mathrm{m}$ & & & & & 0.15 & 0.32 & & & & \\
\hline SHO Odacantha melanura m $\Phi$ & 0.28 & & & & & & & & & \\
\hline
\end{tabular}


Table 3 continued

\begin{tabular}{|c|c|c|c|c|c|c|c|c|c|c|}
\hline \multirow[t]{2}{*}{ Species } & \multicolumn{2}{|c|}{$\begin{array}{l}\text { A1a wet, } \\
\text { open shores }\end{array}$} & \multicolumn{2}{|c|}{$\begin{array}{l}\text { A2 moist } \\
\text { forests }\end{array}$} & \multicolumn{2}{|c|}{$\begin{array}{l}\text { A3 mesic } \\
\text { forests }\end{array}$} & \multicolumn{2}{|c|}{$\begin{array}{l}\text { A4 mesic/dry } \\
\text { forests }\end{array}$} & \multicolumn{2}{|c|}{$\begin{array}{l}\text { A6 mesic/dry } \\
\text { meadows }\end{array}$} \\
\hline & $\mathrm{Su}$ & $\mathrm{Au}$ & $\mathrm{Su}$ & $\mathrm{Au}$ & $\mathrm{Su}$ & $\mathrm{Au}$ & $\mathrm{Su}$ & $\mathrm{Au}$ & $\mathrm{Su}$ & $\mathrm{Au}$ \\
\hline$\sum$ Wetland species & 22.50 & 3.86 & 24.19 & 19.60 & 4.61 & 11.70 & 1.68 & 28.78 & 0.41 & $>32.07$ \\
\hline$\sum$ Other forest species & 0.28 & 0 & 2.77 & 4.80 & 11.85 & 6.32 & 38.90 & 5.91 & 1.03 & 8.16 \\
\hline$\sum$ Other Carabidae & 0.56 & 0 & 4.12 & 0.30 & 3.39 & 1.89 & 3.72 & 8.72 & 29.00 & 31.08 \\
\hline Investigation time (min) & 640 & 140 & 1150 & 200 & 390 & 190 & 145 & 325 & 290 & 250 \\
\hline
\end{tabular}

Figures from summer and autumn within each habitat are comparable. Values in bold are significantly higher $(p<0.05$, Mann-Whitney $U$ test $)$ than those in italics. For further explanation see Table 2

Table 4 Number of individuals of wetland species and other groups of Carabidae collected per hour in May-August (Su) and in late September and October $\mathrm{Au})$ in habitats far from permanently open water. For further explanation see Table 2

\begin{tabular}{|c|c|c|c|c|c|c|c|c|}
\hline \multirow[t]{2}{*}{ Species } & \multicolumn{2}{|c|}{ B1 dry-mesic forests } & \multicolumn{2}{|c|}{ B2 dry meadows } & \multicolumn{2}{|c|}{ B3 mesic, anthropogenic sites } & \multicolumn{2}{|c|}{ B4 dry, antropogenic sites } \\
\hline & $\mathrm{Su}$ & $\mathrm{Au}$ & $\mathrm{Su}$ & $\mathrm{Au}$ & $\mathrm{Su}$ & $\mathrm{Au}$ & $\mathrm{Su}$ & $\mathrm{Au}$ \\
\hline SHO Bembidion illigeri $\mathrm{m}$ & & & & & & & & $0.07^{\mathrm{b}}$ \\
\hline SHO B. lunulatum $\mathrm{m}$ & & & & & $0.07^{\mathrm{a}}$ & & & \\
\hline SHO B. guttula $\mathrm{d}$ & & & & & 0.04 & & & $0.07^{\mathrm{b}}$ \\
\hline FOR Pterostichus nigrita $\mathrm{m}$ & & & & 0.35 & & & & $0.35^{\mathrm{b}}$ \\
\hline FOR $P$. anthracinus $\mathrm{d}$ & & & & & & & & 0.07 \\
\hline FOR Oxypselaphus obscurus b & & & & & & & 0.02 & \\
\hline SHO Aculpalpus parvulus $\mathrm{m}$ & & & & & & & & 0.07 \\
\hline$\sum$ Wetland species & 0 & 0 & 0 & 0.35 & 0.11 & 0 & 0.02 & 0.63 \\
\hline$\sum$ Other forest species & 8.00 & 2.29 & 0.34 & 1.21 & 1.09 & 1.6 & 0.15 & 0.70 \\
\hline$\sum$ Other Carabidae & 6.65 & 1.71 & 74.36 & 49.55 & 46.68 & 23.64 & 71.61 & 59.72 \\
\hline Investigation time (min) & 460 & 105 & 3,380 & 695 & 1,606 & 335 & 5,170 & 860 \\
\hline
\end{tabular}

${ }^{a}$ Close to a temporary puddle

b Temporary puddles at least partly present $<50 \mathrm{~m}$ apart

That the beetles frequently hibernate in holes in the soil, also reduces the risk of inoculative freezing (Sømme 1995).

Krogerus (1948) has postulated that wetland carabid beetles may hibernate far from open water, migrating by flight. However, the present investigation and information given by Lindroth (1945, 1986), Murdoch (1966) and Bauer (1974) reveal that among the species mentioned by Krogerus (1948), Carabus clatratus, Elaphrus cupreus, Pterostichus minor, P. nigrita, Chlaenius tristis, Badister peltatus, B. dilatatus, Panagaeus cruxmajor, Agonum viduum and A. piceum at least in part hibernate adjacent to freshwater fringes. Moreover, Carabus clatratus and Pterostichus minor together with Carabus granulatus, Bembidion clarkii, B. mannerheimi, Badister sodalis, Agonum fuliginosum, Pterostichus vernalis, $P$. anthracinus, $P$. diligens and Oxypselaphus obscurus are mostly or exclusively brachypterous (flightless) on Öland (Table 6; Lindroth 1945, 1949). The main parts of their populations may therefore not be able to move far from open water (see also Dawson (1965) regarding the two last species).
Chlaenius tristis has been described as hibernating in pine forest far from shores in Central Europe (Lindroth 1945, 1949). The present study also shows that the species can hibernate close to lake shores albeit in dry surroundings. The occurrence of two specimens of $C$. tristis in dry forest in May (habitat A4, Table 3) may be due to the species being very hygrophilous in the breeding phase, but also highly thermophilous (Krogerus 1948; Lindroth 1986). Most likely, therefore, the beetles remained in their winter quarter in the forest due to too low a temperature for migration. Krogerus (1948) also observed that, because of its temperature sensitivity, $C$. tristis left its summer habitat on the shores earlier in the autumn than most other wetland carabid beetles. $C$. tristis may therefore pass an extended period in its winter quarters compared with other wetland species.

Blethisa multipunctata, Dyschirius tristis, Bembidion articulatum, B. obliquum, Anthracus consputus, Chlaenius nigricornis and Oodes helopioides occurred in wet or moist habitats in summer, but they were not encountered there in 
Table 5 Summary of information about hibernation conditions of those wetland carabid beetles that wer collected by the present investigations on Öland

\begin{tabular}{|c|c|c|c|c|c|c|c|c|c|}
\hline \multirow[t]{2}{*}{ Species } & \multicolumn{2}{|c|}{ A1 open wetland } & \multicolumn{3}{|c|}{ Forests close to water } & \multirow{2}{*}{$\begin{array}{l}\text { Meadows close } \\
\text { to water } \\
\text { A5-A6 } \\
\text { Dry/mesic }\end{array}$} & \multirow{2}{*}{$\begin{array}{l}\text { Far from } \\
\text { water B 1- } 4\end{array}$} & \multirow[t]{2}{*}{ Specifications } & \multirow[t]{2}{*}{ Sources } \\
\hline & $\begin{array}{l}\text { a } \\
\text { Wet }\end{array}$ & $\begin{array}{l}\mathrm{b} \\
\text { Moist }\end{array}$ & $\begin{array}{l}\text { A } 2 \\
\text { Moist }\end{array}$ & $\begin{array}{l}\text { A3 } \\
\text { Mesic }\end{array}$ & $\begin{array}{l}\text { A4 } \\
\text { Dry/mesic }\end{array}$ & & & & \\
\hline Carabus clatratus $* \phi$ & & & & & + & & & $\mathrm{S}$ & 6 \\
\hline C. granulatus & & & & & & + & & $\mathrm{S}, \mathrm{T}$ & $1,5.6$ \\
\hline Elaphrus cupreus & & & & & & & & $\mathrm{B}$ & 4 \\
\hline Asaphidion flavipes & & & & & & + & & M & 6 \\
\hline Bembidion illigeri & & & & & & & $+^{\circ}$ & $\mathrm{S}$ & 6 \\
\hline B. gilvipes & & + & & & & & & $\mathrm{L}$ & 2,6 \\
\hline B. doris & & + & + & & & & & $\mathrm{L}$ & 2,6 \\
\hline B. fumigatum & & + & + & & & + & & $\mathrm{L}, \mathrm{S}$ & 6 \\
\hline B. assimile & $+?$ & + & + & + & + & + & & $\mathrm{L}, \mathrm{S}$ & 6 \\
\hline B clarkii & & + & + & & & + & & $\mathrm{L}, \mathrm{S}$ & 6 \\
\hline B. aеnеum & & & & & & + & & $\mathrm{S}$ & 6 \\
\hline B. guttula & & + & & & & + & $+^{\mathrm{a}}$ & M & 2,6 \\
\hline Pterostichus vernalis & & + & + & + & + & + & & $\mathrm{L}, \mathrm{M}, \mathrm{S}$ & 6 \\
\hline P. gracilis* & & & & & + & + & & $\mathrm{M}, \mathrm{S}$ & 6 \\
\hline P. nigrita & & & + & + & + & + & $+^{\mathrm{a}}$ & $\mathrm{L}, \mathrm{S}$ & 6 \\
\hline P. anthracinus & & & & + & + & + & + & M, S & 6 \\
\hline P. minor & & & & + & + & & & $\mathrm{L}, \mathrm{S}, \mathrm{T}$ & 3,6 \\
\hline$P$. diligens & $+?$ & + & & & & & & $\mathrm{L}, \mathrm{M}, \mathrm{S}$ & 2,6 \\
\hline Platynus livens* & & + & + & + & + & + & & $\mathrm{S}, \mathrm{T}$ & 5,6 \\
\hline Oxypselaphus obscurus & & & & & & + & & $\mathrm{L}, \mathrm{M}, \mathrm{T}$ & $2,3,6$ \\
\hline Agonum thoreyi & & + & + & + & & + & & $\mathrm{H}, \mathrm{M}, \mathrm{T}$ & $2,5,6$ \\
\hline A. piceum & + & & + & & & & & $\mathrm{M}, \mathrm{S}, \mathrm{T}$ & 5,6 \\
\hline A. fuliginosum & $+?$ & & & & & + & & $\mathrm{L}, \mathrm{M}, \mathrm{T}$ & $2,3,6$ \\
\hline A. viduum & & & + & + & & + & & $\mathrm{S}$ & 6 \\
\hline A. emarginatum $\Phi$ & & & & & + & + & & $\mathrm{M}, \mathrm{S}$ & 6 \\
\hline A. lugens* & & & + & + & + & + & & $\mathrm{S}, \mathrm{T}$ & $1,5,6$ \\
\hline Stenolophus mixtus & & & & & + & + & & $\mathrm{S}$ & 6 \\
\hline Trichocellus placidus & & & & & + & & & $\mathrm{L}$ & 2,6 \\
\hline Aculpalpus parvulus & & & + & & & + & $+^{\mathrm{a}}$ & $\mathrm{S}$ & 6 \\
\hline Panagaeus cruxmajor ${ }^{*} \Phi$ & & & & + & + & + & & $\mathrm{L}, \mathrm{S}, \mathrm{T}$ & 5,6 \\
\hline Chlaenius tristis $* \Phi \times$ & & & & & + & & $+{ }^{\mathrm{b}}$ & $\mathrm{S}$ & 1,6 \\
\hline Badister unipustulatus* & & & + & & + & + & & $\mathrm{M}, \mathrm{S}, \mathrm{T}$ & 5,6 \\
\hline B. sodalis $\Phi$ & & & + & & & & & $\mathrm{L}$ & 6 \\
\hline B. peltatus $* \Phi$ & & & + & & & & & $\mathrm{L}$ & 6 \\
\hline B. dilatatus $\Phi$ & & & + & & & & & M & 6 \\
\hline B. collaris & & & & + & & & & $\mathrm{L}$ & 6 \\
\hline Odacantha melanura $\Phi$ & + & & & & & & & $\mathrm{H}$ & 5 \\
\hline
\end{tabular}

Sources: 1, Lindroth (1945, 1949); 2, Krogerus (1948); 3, Murdoch (1966); 4, Bauer (1974); 5, Lindroth (1985-1986); ; 6, present investigation. For further explanation of symbols see Table 2

$B$ burried in the soil, $H$ in hollow stems of plants, e.g. reed; $L$ among litter, $M$ under moss, $S$ under stones, $T$ in tree stumps or under bark

a Temporary puddles present $<50 \mathrm{~m}$ from the sites

b Observation from Central Europe

autumn. Although all these species have flight ability, it is unlikely that they migrate far from the shore by flight because the flight activity of wetland carabid beetles seems to be very low in September and later in the year. This is, for example, indicated by a study of anemohydrochore dispersal of beetles across the Baltic Sea (Baranowski and 
Table 6 Wing development of specimens of nine species, which according to Lindroth $(1945,1949)$, are dimorphic (or polymorphic) or mainly brachypterous

\begin{tabular}{llllll}
\hline Species & \multicolumn{3}{l}{ Wing development } & & \\
\cline { 2 - 3 } & $\mathrm{a}$ & $\mathrm{b}$ & $\mathrm{c}$ & $\chi^{2}$ & $p$ \\
\hline Bembidion assimile & 12 & 33 & 9.80 & $<0.01$ \\
B. clarkii & 13 & & 1 & 10.29 & $<0.01$ \\
B. guttula & 1 & & 2 & & \\
Pterostichus vernalis & 23 & 2 & 1 & 22.15 & $<0.001$ \\
P. anthracinus & 35 & 1 & & 36.00 & $<0.001$ \\
P. minor & 23 & 2 & 3 & 17.29 & $<0.001$ \\
P. diligens & 25 & & & 25.00 & $<0.001$ \\
Agonum emarginatum & & 5 & 10 & 1.67 & $\mathrm{~ns}$ \\
A. fuliginosum & 14 & & & 14.00 & $<0.001$ \\
\hline
\end{tabular}

The material stems from Öland. The differences in the frequency between $\mathrm{a}+\mathrm{b}$ and $\mathrm{c}$ were tested by means of chi square tests

$n s$ not significant $(p>0.05)$

a, Brachypterous. Wings without reflexed apical part, shorter and more narrow than one elytron. Without flight ability; $b$, Wings of about same length or somewhat longer than the elytra, reflexed apical part not well developed, flight ability dubious; c, Macropterous. Wings much broader and longer than one elytron. Well developed reflexed apical part. With flight ability

Gärdenfors 1974) in which vast numbers of individuals of wetland Carabidae species, including a majority of those mentioned above, were observed washed ashore in summer (especially in June). In September, on the contrary, very few species and specimens were found irrespective of temperature and wind conditions. Likewise, Bonn and
Helling (1997) found high flight activity of carabid beetles near the river Elbe in June, but low flight activity in autumn. Numerous observations of flying individuals of wetland species of e. g. Bembidion and Stenolophus have also been made in the period May-August, but not later in the year (Lindroth 1945, 1949; Andersen 1966, 1970, 1997; Matalin 1992, 2003).

Finding low numbers of individuals of some wetland species far from permanent water bodies in autumn (habitats B2, B4) can hardly be used as convincing evidence of a regular long distance dispersal by flight. Additionally, temporary puddles are situated close to at least two of the dry, anthropogenic sites that were studied and areas around puddles may harbour populations of some wetland species even in summer.

The conclusion from this study, at least in Scandinavia, is that there is hardly any evidence that wetland carabid beetles migrate regularly far from open water by flight in autumn. They seem to have two hibernation strategies: (1) Beetles remain in the wetlands, albeit usually not in watery surroundings. (2) A high number of species and individuals radically shift habitat and move to elevated sites such as mesic to dry meadows and forests situated close to water. These migrations obviously take place per pedes. Individual species may adopt both strategies. The beetles hibernate among litter, under moss, bark or large stones, in tree stumps or burried in the soil.

Some of the reasons why the winter quarters of several wetland carabid beetles are still unknown are suggested by the current information. Hence, species may hibernate rather close to water, but buried in the soil as is the case

Table 7 Ratio of individuals of some categories of wetland species in relation to exposure and distance from water

\begin{tabular}{|c|c|c|c|c|}
\hline \multirow[t]{2}{*}{ Habitats } & \multicolumn{2}{|c|}{$\mathrm{FOR} / \mathrm{FOR}+\mathrm{SHO}$} & \multirow{2}{*}{$\begin{array}{l}\text { Wing development } \\
\text { Macr/Macr + Dim } \\
\mathrm{Au}\end{array}$} & \multirow{2}{*}{$\begin{array}{l}\text { Size }(\mathrm{mm}) \\
\geq 7 / \geq 7+<7 \\
\mathrm{Au}\end{array}$} \\
\hline & $\mathrm{Su}$ & $\mathrm{Au}$ & & \\
\hline Open (A1, A6) & $0.10(0.07)$ & $\geq 0.78(0.29)$ & & \\
\hline Forest (A2, A3, A 4) & $0.94(0.93)$ & $0.72(0.47)$ & & \\
\hline Close to water $(\mathrm{A} 1, \mathrm{~A} 2)$ & & & 0.32 & $<0.01$ \\
\hline Farther from water $\left(\mathrm{A} 3, \mathrm{~A} 5^{\mathrm{a}}\right)$ & & & 0.27 & 0.19 \\
\hline$\chi^{2}$ & $138.27(137.18)$ & $-(5.32)$ & 0.39 & 18.39 \\
\hline$p$ & $* * *(* * *)$ & $-(*)$ & ns & $* * *$ \\
\hline$N$ & $248(233)$ & $\geq 493$ (209) & 213 & 213 \\
\hline
\end{tabular}

Bembidion assimile and Agonum emarginatum are dimorhic, but they were regarded as macropterous, since a majority of the individuals seems to have flight ability on Öland (Table 5). The material regarding the frequencies of SHO and FOR species stems from a single lake and its immediate vicinity, the rest of the material is from the same lake and a mire. Numerals in brackets are based on data without Pterostichus anthracinus and $P$. nigrita. Chi square tests including data of these species from autumn could not be performed due to lack of exact information about number of specimens. Data from habitat A 5 are based on investigation under moss and sieving (method 5, see Table 1). Data for A2 from August 2005 and May 2006 were ommitted due to high water level

$A u$ autumn, $S u$ summer, $N$ number of specimens, FOR forest species, SHO shore species, Macr macropterous, Dim dimorphic or brachypterous, $n s$ not significant

$* p<0.05, * * * p<0.001$

${ }^{a}$ Method 5 (see Table 1) 
with Elaphrus spp. (Bauer 1974) and they are therefore rarely discovered by means of conventional sampling methods. Other species are rare and/or may aggregate in their winter quarters which reduces the probability of finding individuals.

Bembidion petrosum, which prefer open river banks with little or no vegetation, orients towards directed light at high temperatures. This response keeps the species in open habitats during the reproduction period in spring (Andersen 1989). With decreasing temperatures in autumn, however, the response of the species changes to a positive orientation towards silhouettes. This orientation, combined with lower moisture requirements in autumn, leads the beetles away from the reproduction habitat to the winter quarters which are situated in the elevated parts of the river banks (Andersen 1968, 2006). Several other species prefer open habitats in summer and avoid overgrown sites. The shift from summer to winter habitat of such species may be governed by some of the same factors as those applying to Bembidion petrosum.

\section{Conservation aspects}

A substantial number of species that are red- listed in at least one of the countries in Scandinavia were detected in this study and eleven of the red-listed species were found in their hibernation locale. Mesic to dry forests and meadows high above, but close to fens and lakes provide winterquarters for a majority of these species. Among the red-listed species hibernating in such habitats, Carabus clatratus, Panagaeus cruxmajor and Chlaenius tristis are vulnerable or endangered in many parts of their distributional ranges (Gärdenfors et al. 2002; Turin et al. 2003; Ødegaard et al. 2006; DMU 2007). It is likely that other wetland species with unknown winter quarters hibernate in similar habitats. To support the whole assemblage of wetland species, it is therefore of crucial importance to manage mesic and dry forests and meadows close to fens and lakes adequately. Various kinds of exploitations such as logging and destruction of meadows, e.g. by digging or removal of stones, must be avoided in such areas. Because beetles are mainly inactive during the winter, destruction or disturbance of their hibernation sites will have a severe impact on their ability to overwinter.

Wear and tear, and especially trampling by livestock, will have a substantial negative effect on the beetle fauna of most of the habitats on river banks with exposed riverine sediments (Andersen and Hanssen 2005; Bates et al. 2007). However, the effect of trampling and grazing seems to be rather the opposite at the fringes of more stable water systems (Sadler et al. 2004). The shores, meadows and forests at or near some of the lakes on Öland, for instance, are heavily grazed by cattle. Consequently, the shores of the lakes have a low and partly sparse vegetation. This evidently creates favourable reproduction habitats for species like Carabus clatratus, Chlaenius nigricornis, C. tristis and Panagaeus cruxmajor because these beetles do not tolerate overgrowth (Gärdenfors et al. 2002; Ljungberg 2002; Turin et al. 2003). It is likely that grazing also generates suitable winter quarters for such species.

In conclusion, the current study shows that it is absolutely necessary to protect all the habitats in the immediate vicinity of mires and lakes to save their wetland fauna. The importance of mesic and dry meadows and wooded areas adjacent to wetlands should be especially emphasized since such habitats may constitute winter quarters for a majority of rare and red-listed wetland Carabidae species (see also Rothenbücher and Schaefer (2006)). Threats to the winter quarters are exploitation and various transformations of the habitats, such as logging and digging. Cessation of grazing may also have a negative effect. It would be a mistake to base the management of rare and red-listed species on a nearly undocumented assertion that the winter quarters of the wetland species may be present somewhere far from wetlands (see group 3 in Lott (2003)).

Acknowledgments I would like to thank two anonymous referees for valuable comments on the manuscript.

Open Access This article is distributed under the terms of the Creative Commons Attribution Noncommercial License which permits any noncommercial use, distribution, and reproduction in any medium, provided the original author(s) and source are credited.

\section{References}

Alexanderson H, Karlström C, Lasson-Mc Cann S (1991) Temperature and precipitation in Sweden 1961-1990. Reference normals. SMHI Meteorologi. Klimasektionen 81, Norrköping

Andersen J (1966) Økologiske unders $\emptyset$ kelser av noen stenotope elvebreddarter av slekten Bembidion Latr. (Carabidae). Unpublished thesis, University of Oslo, Oslo

Andersen J (1968) The effect of inundation and choice of hibernation sites of Coleoptera living on river banks. Norsk ent Tidsskr $15: 115-133$

Andersen J (1970) Habitat choice and life history of Bembidiini (Col Carabidae) on river banks in central and northern Norway. Norsk ent Tidsskr 17:17-65

Andersen J (1978) The influence of the substratum on the habitat selection of Bembidiini (Col., Carabidae). Norw J Entomol 25:119-138

Andersen J (1983) The habitat distribution of species of the tribe Bembidiini (Coleoptera, Carabidae) on banks and shores in northern Norway. Notul Entomol 63:131-142

Andersen J (1985a) Humidity responses and water balance of riparian species of Bembidiini (Col., Carabidae). Ecol Entomol 10: 363-375

Andersen J (1985b) Low thigmo-kinesis, a key mechanism in habitat selection by riparian Bembidion (Carabidae) species. Oikos 44:499-505 
Andersen J (1986) Temperature response and heat tolerance of riparian Bembidiini species (Coleoptera: Carabidae). Entomol Gener 12:57-70

Andersen J (1989) Photoresponse of carabid beetles depends on experimental design. Oikos 54:195-200

Andersen J (1997) Habitat distribution of riparian species of Bembidiini (Col., Carabidae) in South and Central Norway. Fauna norv B 44:11-25

Andersen J (2000) What is the origin of the carabid beetle fauna of dry, anthropogenic habitats in western Europe? J Biogeogr 27:795-806

Andersen J (2006) Mechanisms in the shift of a riparian ground beetle (Carabidae) between reproduction and hibernation habitat. J Insect Behav 19:545-558

Andersen J, Hanssen O (2005) Riparian beetles, a unique, but vulnerable element in the fauna of Fennoscandia. Biodivers Conserv 14:3497-3524

Arneberg P, Andersen J (2003) The energetic equivalence rule rejected because of a potentially common sampling error: evidence from carabid beetles. Oikos 101:367-375

Baranowski R, Gärdenfors U (1974) Vinddrift av jordlöpare i sydöstra Skåne. Entomologen 3:35-52

Bates AJ, Sadler JP, Fowles AP (2007) Livestock trampling reduces the conservation value of beetle communities on high quality exposed riverine sediments. Biodivers Conserv 16:1491-1509

Bauer T (1974) Ethologische, autökologische und ökophysiologische Untersuchungen an Elaphrus cupreus Dft und Elaphrus riparius L. Oecologia (Berlin) 14:139-196

Bonn A, Helling B (1997) Einfluss von schwankenden Wasserständen auf die Flugaktivität von Laufkäfers. Mitt Dtsch Ges Allg Angew Ent 11:439-442

Chao A (1984) Non-parametric estimation of the number of classes in a population. Scand J Statistics 11:265-270

Dawson N (1965) A comparative study of the ecology of eight species of fenland Carabidae (Coleoptera). J Anim Ecol 34:299-314

Dynesius M, Nilsson C (1994) Fragmentation and flow regulation of river systems in the northern third of the world. Science 266:753-762

Ekstam U, Jacobson R, Mattson M, Porsne T (1984) Ölands och Gotlands växtvärld. En ekologisk och kulturhistorisk flora, Natur och kultur, Stockholm

Freude H, Harde K-W, Lohse GA, Klausnitzer B (2004) Die Käfer mitteleuropas. 2. Adephaga. 1. Carabidae (Laufkäfer). Spektrum, Heidelberg

Gärdenfors U (2005) Rödlistade arter i Sverige. The 2005 red list of Swedish species. ArtDatabanken, SLU, Uppsala

Gärdenfors U, Aagaard K, Biström O, Holmer M (2002) Hundraelva nordiska evertebrater. Handledning för övervakning av rödlistade småkryp. Nord 2002: 3. Nordiska Ministerrådet och ArtDatabanken

Greenstone HM (1979) A line transect density index for wolf spiders (Pardosa spp.) and a note on the applicability of catch per unit effort methods to entomological studies. Ecol Entomol 4:23-29

Hansen V (1968) Biller 24 Sandspringere og Løbebiller (Cicindelidae og Carabidae). Danmarks Fauna 76:1-451

Huk T, Kühne B (1999) Substrate selection by Carabus clatratus (Coleoptera, Carabidae) and consequences for offspring development. Oecologia (Berlin) 121:348-543

Kleinwächter M, Burkel M (2008) Offspring performance in dynamic habitats: key factors for a riparian carabid beetle. Ecol Entomol 33:286-292

Kolesnikov FN (2008) Sex and age structure of population, developmental biology, and parental care in Pterostichus (Pseomaseus) anthracinus (Coleoptera, Carabidae) in the Desna River flood plain. Zool Zh 87:1205-1210

Krogerus H (1948) Ökologische Untersuchungen über Uferinsekten. Acta Zool Fenn 53:1-157
Lid J, Lid D (2005) Norsk flora. Det Norske Samlaget, Oslo

Lindroth CH (1961-1969) The ground-beetles (Carabidae, excl. Cicindelidae) of Canada and Alaska. 1-6. Opusc Ent (Suppl). 20, 24, 29, 33, 34, 35

Lindroth CH (1985-1986) The Carabidae (Coleoptera) of Fennoscandia and Denmark. Fauna entomol Scand 15 (1-2):1-497

Lindroth C H (1945) Die fennoskandischen Carabidae. I. Spezieller Teil. Göteborgs Kungl Vetensk—o Vitterh Samh Handl B 4:1-709

Lindroth C H (1949) Die fennoskandischen Carabidae. III. Allgemeiner Teil. Göteborgs Kungl Vetensk—o Vitterh Samh Handl B 4: $1-911$

Ljungberg H (2002) Våra rödlistade jordlöpares habitatkrav. Entomol Tidskr 123:167-185

Lott DA (2003) An annotated list of wetland ground beetles (Carabidae) and rove betles (Staphylinidae) found in the British Isles including a literature review of their ecology. English Nature Research Reports 488. English Nature, Peterborough

Matalin AV (1992) Relationships between ground and flight relocations in populations of dominant species of carabid beetles (Insecta, Carabidae) in the south-west of the steppe zone. Ent Rev 71:119-130

Matalin AV (2003) Variations in flight ability with sex and age in ground beetles (Coleoptera, Carabidae) of south-western Moldova. Pedobiologia 47:311-319

Moen A (1998) Nasjonalatlas for Norge: Vegetasjon. Statens kartverk, Hønefoss

Mossberg B, Stenberg L (2007) Gyldendals store nordiske flora. Gyldendal, Oslo

MU D (2007) Den danske rødliste. National Environmental research Institute, Denmark

Murdoch WW (1966) Aspects of the population dynamics of some marsh Carabidae. J Anim Ecol 35:127-156

Ødegaard F (2006) Impact factors and environmental status. In: Kålås JA, Viken A, Bakken T (eds) 2006 Norwegian Red list. Artsdatabanken, Norway, pp 61-94

Ødegaard F, Andersen J, Hansen O, Kvamme T, Olberg S (2006) Biller. Coleoptera. In: Kålås JA, Viken Å, Bakken T (eds) 2006 Norwegian Red list. Artsdatabanken, Norway, pp 237-266

Paje F, Mossakowski D (1984) pH-preference and habitat selection in Carabid beetles. Oecologia (Berlin) 64:41-44

Pringle CM (1997) Fragmentation in stream ecosystems. In: Meffe GK, Carrol CR (eds) Principles of conservation biology. Sinauer, Sunderland, pp 289-290

Rothenbücher J, Schaefer M (2006) Submersion tolerance in floodplain arthropod communities. Basic Appl Ecol 7:398-408

Sadler JP, Bell D, Fowles A (2004) The hydroecological controls and conservation value of beetles on exposed riverine sediments in England and Wales. Biol Cons 118:41-56

Schreiner R, Irmler U (2009) Niche differentiation and preferences of Elaphrus cupreus Duftschmid, 1812 and Elaphrus uliginosus (Fabricius, 1792) (Coleoptera: Carabidae) as reason for their different endangerment in Central Europe. J Insect Conserv 13:193-202

Siepe A (1994) The "flooding behaviour" of carabid beetles (Coleoptera, Carabidae) in river floodplains: ecological and ethological adaptations to periodic inundations. Zool Jb Syst 121:515-566

Sømme L (1995) Invertebrates in hot and cold arid environments. Springer, Berlin

Sowig P (1986) Experimente zur Substratpäferenz und zur Frage der Konkurrenzverminderung uferbewohnender Laufkäfer (Coleoptera, Carabidae). Zool Jb Syst 113:55-57

Thiele H-U (1977) Carabid beetles in their environments. A study on habitat selection by adaptations in physiology and behaviour. Springer, Berlin

Turin H, Penev L, Casale A (2003) The genus Carabus in Europe. A synthesis. Pensoft, Sofia 